\title{
Jute seed production as influenced by dates of sowing and topping in red and laterite zone of West Bengal
}

\author{
Bikas Chandra Patra*, Nirmal Kumar Dinda, Korla Aditya Chowdary and Milan \\ KantiKundu
}

Department of Agronomy, Bidhan Chandra Krishi Viswavidyalaya, Mohanpur, Nadia -741252 (West Bengal), INDIA

*Corresponding author's e-mail: bikascpatra@gmail.com

Received: December 16, 2016; Revised received: March 22, 2017; Accepted: August 5, 2017

\begin{abstract}
An experiment was carried out during thekharif season of two consecutive years 2014 and 2015 at Regional Research Sub-station, Raghunathpur, Bidhan Chandra Krishi Viswavidyalaya, Purulia, West Bengal with the view to maximise the jute seed yield by manipulating certain non-monetary techniques like dates of sowing and topping associated with crop production. The Capsularis variety Bidhan pat-3 was sown in three different dates ( $1^{\text {st }}$ $25^{\text {th }}$ June, $2^{\text {nd }}-15^{\text {th }}$ July and $3^{\text {rd }}-5^{\text {th }}$ August) with 3 topping (clipping of apical portion) practices at 30,45 and 60 days after sowing (DAS) as separate treatment with no topping as control. These different agronomic practices significantly (at $5 \%$ probability level) influenced the performance of the crop in various aspects. The $1^{\text {st }}$ date of sowing showed its supremacy in terms of expression of the crop in the field in all the aspects achieving a seed yield of $709.50 \mathrm{~kg} \mathrm{ha}^{-1}$ and $737.85 \mathrm{~kg} \mathrm{ha}^{-1}$ during first and second year respectively, whereas, the last date of sowing showed its inferiority obtaining a seed yield of $590.10 \mathrm{~kg} \mathrm{ha}^{-1}$ and $647.13 \mathrm{~kg} \mathrm{ha}^{-1}$ all through the first and second year respectively. $1^{\text {st }}$ date of sowing also recorded higher net return(Rs. $33721.50 \mathrm{ha}^{-1}$ \& Rs.35989.50 ha ${ }^{-1}$ during first and second year) and benefit: cost ratio (1.46 and 1.56 in first and second year) over the other two date of sowing. However, maximum seed yield was achieved when the crop was topped on 45 DAS $\left(728.80 \mathrm{~kg} \mathrm{ha}^{-1}\right.$ and $773.57 \mathrm{~kg} \mathrm{ha}^{-1}$ during first and second year) irrespective of the date of sowing.
\end{abstract}

Keywords: Date of sowing, Economics, Jute, Seed yield, Topping

\section{INTRODUCTION}

Jute is one of the most important commercial bast fibre crops which occupy a key place in the Indian economy. In West Bengal,it is the most important fibre crop occupying an area of 519 thousand ha with a production of 8075 thousand bales (Anonymous, 2016). In west bengal, it is mainly grown for fibre production in the alluvial tract. Besides, the leaves and soft stems are also consumed as vegetables as they supply energy, minerals, vitamins and many more (Antia et al., 2006).

Now a day, the jute has been facing a strong competition from the synthetic materials prevailing in the market. Therefore, there is a felt need to augment the jute production considerably to make its cultivation profitable to the farmers. One of the most vital keys to success in our endeavour for higher fibre production, improved quality seed is an important input. It has been reported that quality seeds of an improved variety can itself provide 20 percent additional yield of the crop (Hossain et al., 1994) over that obtained from the use of local seed. But, these quality seeds are generally unavailable to the jute growers of the West Bengal. The farmers usually met their requirement by the N.S.C where the seeds are grown under its supervision in the states like Bihar, Andhra Pradesh and Maharashtra which in turn increases the cultivation cost significantly. On this contrary, in West Bengal areas like Bankura, Purulia, Midnapore, parts of Birbhum and Burdwan can be used for the seed production of jute as the prevailing agro-climatic conditions are congenial for this purpose.

Jute seed production can be increased significantly by adopting improved agronomic techniques. Among the improved agronomic techniques, Optimum sowing time is an important factor as the jute requires a well-distributed monsoon rains during the vegetative period and a rain free period during ripening to harvesting and processing for its seed production. When the crop is sown at its optimum time, there is a synchronisation of the growth phases of the crop with the optimum environmental condition which ultimately leads to better expression of the crop in terms of growth and yield (Salmasiet al., 2006). Another important factor is topping (clipping of apical buds). When the apical buds are clipped off, the auxiliary buds develop lateral branches which in turn increases the seed yield by producing more number of pods. However, the practice of topping has been proved effective in increasing the yield levels of white jute (Das et al., 2014). Keeping all these factors in mind a field 
experiment was conducted during the kharif season of 2014 and 2015 at the Regional Research Sub-station, Raghunathpur, Bidhan Chandra KrishiViswavidyalaya with the objective to study and assess the optimum date of sowing for higher seed production with the possibilities of increasing seed yield by topping.

\section{MATERIALS AND METHODS}

Experimental site: The field experiment was conducted at Regional Research Sub-station, Raghunathpur, Bidhan Chandra Krishi Viswavidyalaya, Purulia, West Bengal in two consecutive years of 2014 and 2015. The study area belongs to humid and tropical climate characterised by a wet monsoon season (June to September) and a dry post monsoon season. The experimental site was situated at $23.55^{\circ} \mathrm{N}$ latitude and $86.67^{\circ} \mathrm{E}$ longitude with the altitude of 155 metres above the mean sea level (MSL).

Experimental soil: The soil of the experimental field was sandy clay loam in texture (sand, silt and clay content is 56.2, 20.3 and $23.5 \%$ respectively as determined by the International Pipette Method; Piper, 1966) having good water holding capacity. Fertility status of the experimental soil was medium having $\mathrm{pH}$ of 6.4 with $0.56 \%$ organic carbon, $0.059 \%$ total nitrogen, $18.50 \mathrm{~kg} \mathrm{ha}{ }^{-1}$ available phosphorus and $176.33 \mathrm{~kg} \mathrm{ha}^{-1}$ available potassium.

Experimental design and treatments: The experiment was laid out in Factorial Randomized Block Design. There were 12 treatment combinations comprising 3 dates of sowing $\left(1^{\text {st }}-25^{\text {th }}\right.$ June, $2^{\text {nd }}-15^{\text {th }}$ July and $3^{\text {rd }}-5^{\text {th }}$ August) and 4 topping practices $\left\{1^{\text {st }}\right.$-without topping, $2^{\text {nd }}$ - topping at 30 days after sowing (DAS), $3^{\text {rd }}$ - topping at 45 DAS and $4^{\text {th }}$-topping at 60 DAS) which were replicated thrice. The individual plot size was $5 \mathrm{~m} \times$ $4 \mathrm{~m}$.

Crop management: The jute variety Bidhan pat 3 was sown in three different dates with the seed rate of $6 \mathrm{~kg}$ $\mathrm{ha}^{-1}$ and spacing $30 \mathrm{~cm} \times 10 \mathrm{~cm}$. The fertiliser dose of 60:30:30 kg N, $\mathrm{P}_{2} \mathrm{O}_{5}$ and $\mathrm{K}_{2} \mathrm{O} \mathrm{ha}^{-1}$ was used for the crop. $50 \% \mathrm{~N}$ along with the full dose of $\mathrm{P}_{2} \mathrm{O}_{5}$ and $\mathrm{K}_{2} \mathrm{O}$ were applied as basal at the time of final land preparation and the rest amount of nitrogen was applied at 30 days after sowing (DAS).In order to induce auxiliary branches clipping of the apical portion (topping) was carried out at 30 DAS, 45 DAS and 60 DAS on separate plots. After topping 2\% urea solution was sprayed to remove the stress (only on topped plots). During the first year, the crop was affected by the insect jute semilooper considerably and to control that Fipronil 5 SC @ $1 \mathrm{ml} /$ litre of water was applied at $35 \mathrm{DAS}$ (for $1^{\text {st }}$ and $2^{\text {nd }}$ sowing). In the first year, the crop was harvested on $08 / 11 / 2014$ ( $1^{\text {st }}$ sowing), 15/11/2014 ( $2^{\text {nd }}$ sowing) and $27 / 11 / 2014\left(3^{\text {rd }}\right.$ sowing) taking a total duration of 136, 122 and 113 days respectively. During the second year, the crop was harvested on $11 / 11 / 2015$ ( $1^{\text {st }}$ sowing), 20/11/2015(2 $2^{\text {nd }}$ sowing) and $29 / 11 / 2015$ $\left(3^{\text {rd }}\right.$ sowing) taking a total duration of 139,127 and 115 days respectively.

Plant sampling: For measuring the seed yield of jute, the entire produce from the net plot area (from demarcated portion, leaving the border area) was harvested and weighed after thorough drying under the sun. Seed yield from that area was converted to yield unit $^{-1}$ area $\left(\mathrm{kg} \mathrm{ha}^{-1}\right)$. All the growth parameter (plant height, basal diameter) and yield parameter (pods plant ${ }^{-1}$, seeds pod $^{-1}$ ) were measured by randomly taking 10 plants from each plot and finally averaged into a single value.

Statistical analysis: The critical difference (CD) for estimated treatment contrasts was worked out using standard statistical procedures as outlined in Gomez and Gomez (1984). The difference between treatment means were compared with $\mathrm{CD}$ value at $5 \%$ level of probability and the treatments with higher effect over others were identified.

\section{RESULTS AND DISCUSSION}

Effect of date of sowing and topping on the growth parameter of jute: Plant height data of two consecutive years presented in Table 1. In the first year of experimentation, the treatment ascendancy with respect to plant height was observed with the first date of sowing recording a values of $36.46 \mathrm{~cm}$ at $30 \mathrm{DAS}$, $101.76 \mathrm{~cm}$ at $45 \mathrm{DAS}$ and $168.85 \mathrm{~cm}$ at $60 \mathrm{DAS}$; while, the last date of sowing showed its lowliness (plant height of $30.34 \mathrm{~cm}$ at $30 \mathrm{DAS}, 76.46 \mathrm{~cm}$ at 45 DAS and $118.49 \mathrm{~cm}$ at $60 \mathrm{DAS}$ ). Similar trend was also found in the next year of study in which the first date of sowing outdated all other sowing date with respect to plant height. Best performance in advocating plant height for seed production of jute crop sown on $1^{\text {st }}$ june has also been established by Kumar et al. (2013) and Singh et al. (2013). Topping done on different dates also influenced plant height of the crop significantly at $5 \%$ probability level at different growth stages except at $30 \mathrm{DAS}$. The treatment supremacy regarding plant height at 45 and 60 DAS during both the years was observed under the no topping practices. The plants that were grown without topping achieved the maximum plant height (values being 99.08 and $103.79 \mathrm{~cm}$ at 45 DAS in the first and second year respectively and 158.73 and $151.60 \mathrm{~cm}$ at 60 DAS in both the successive years respectively) and were statistically superior over the others that got some topping at their different growth stages. However, the plants that were topped at 30 DAS recorded lowest plant height. This may be due to the fact that at initial stages the growth of the crop was not hampered up to 30 days as no topping practices were employed before that. But after that when the plants were topped off, it got a physical shock which reduced the growth considerably and became an important factor behind the difference of plant height at different topping 
Bikas Chandra Patra et al. / J. Appl. \& Nat. Sci. 9 (3): 1582 -1586 (2017)

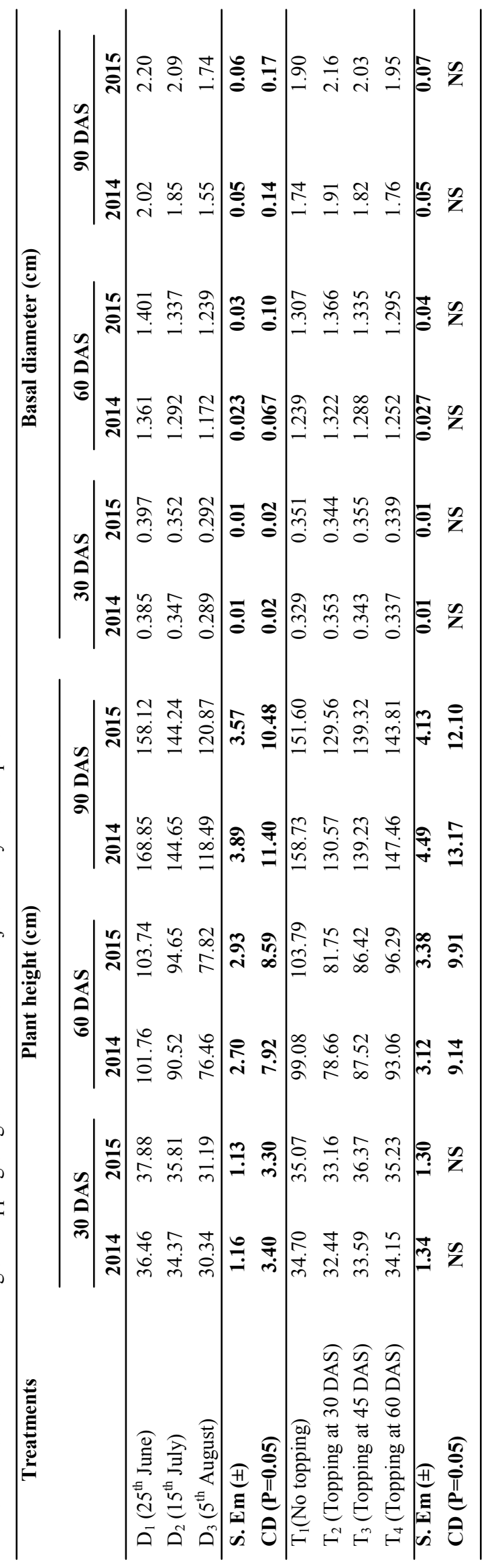

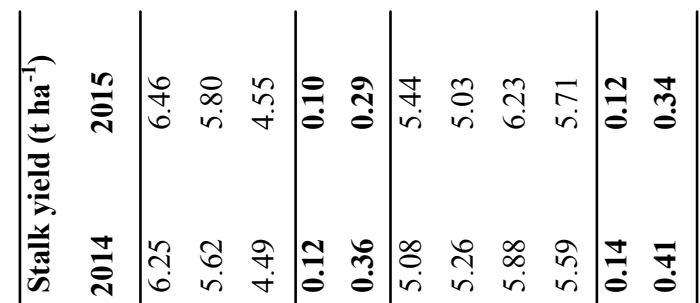

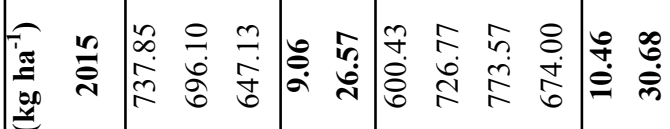
告

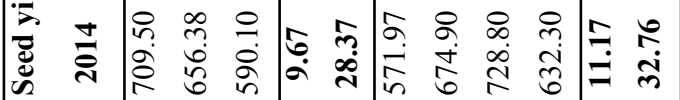

ख

产

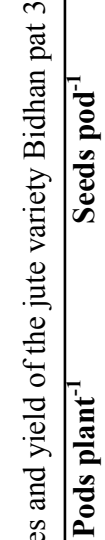

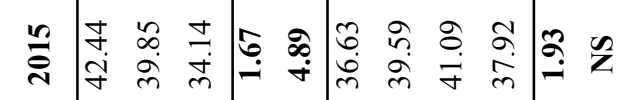

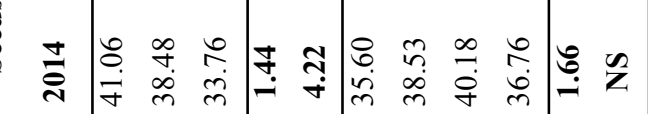

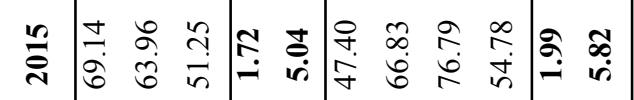

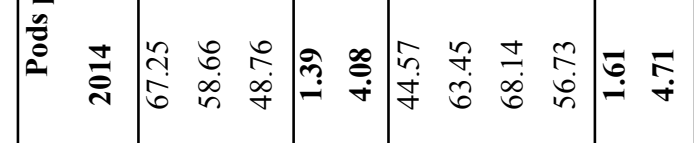

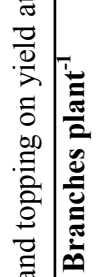

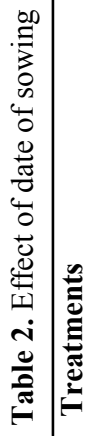

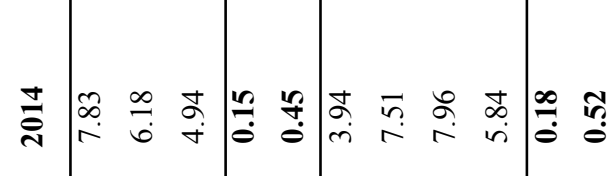

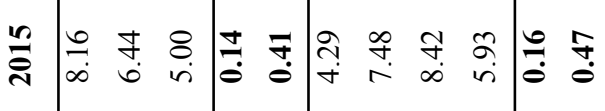

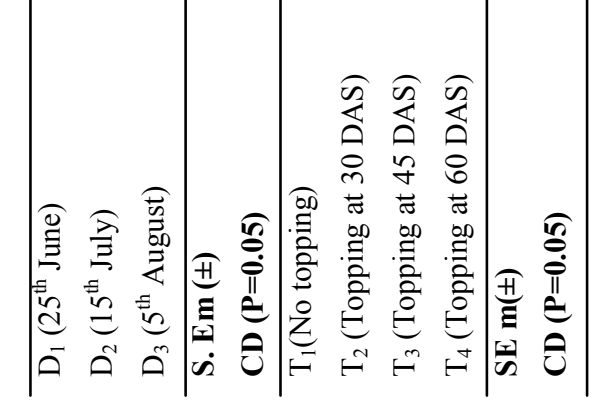


Bikas Chandra Patra et al. / J. Appl. \& Nat. Sci. 9 (3): 1582 -1586 (2017)

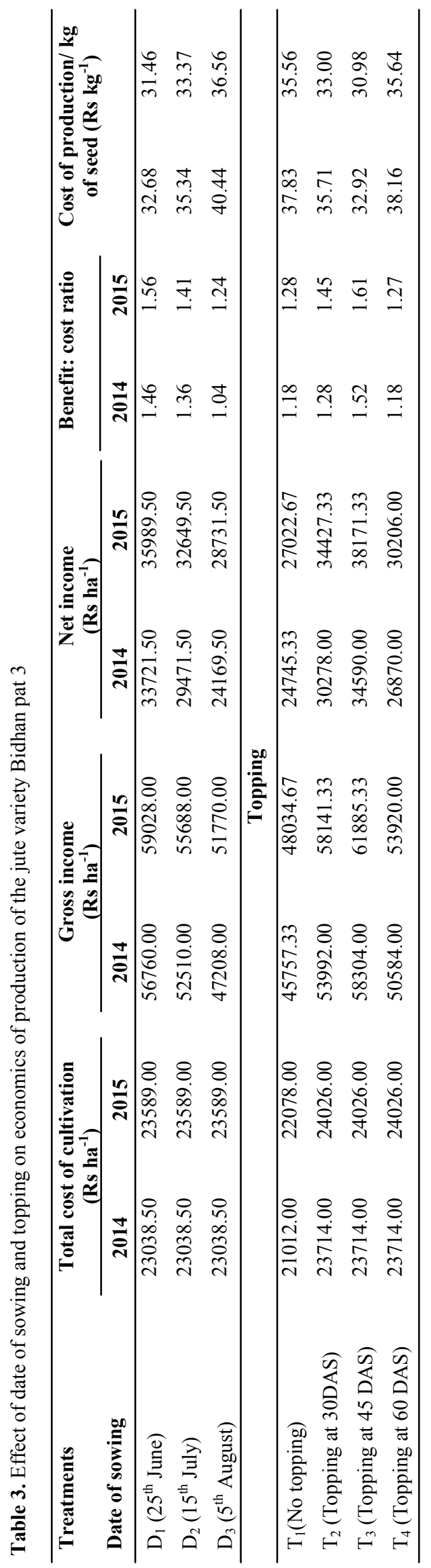

practices. This result corroborated the findings of Mollah et al. (2015) in kenaf crop.

Concerning the effects of sowing date and topping practices on basal diameter of the plant, the data of two years of study as texted in Table 1 exhibited that basal diameter of the plant changed significantly with the different sowing date, while, there was no significant effect of topping practices found on basal diameter of the plant all through the growth stages. The crop sown on $25^{\text {th }}$ June recorded maximum basal diameter all through the growth stage (Table-1) and the crop was sown on $5^{\text {th }}$ August the minimum.

Effect of date of sowing and topping on yield attributes and yields of jute: A noteworthy effect of the date of sowing was evidenced in the case of yield attributes like no of pod plant ${ }^{-1}$ and seed pod $^{-1}$ etc. (Table 2). The treatment supremacy regarding no. of pods plant ${ }^{-1}$ (67.25 and 69.14 in 2014 and 2015 respectively) and no. of seed $\operatorname{pod}^{-1}$ (41.06 and 42.44 in the successive years) were established with the first date of sowing which was statistically superior over the other sowing dates. However, the test weight was not varied significantly under different date of sowing. The better result under $1^{\text {st }}$ date of sowing may be due to the greater interaction of the crop with the environmental factors such as temperature, humidity, rainfall etc. which in turn favoured the growth of the crop considerably. These higher values of all the yield attributes came together positively to escalate the crop yield (both grain and straw yield) in the first date of sowing making it superior over the other two date of sowing (Table 3). These findings are in agreement with those recorded by Rayhan et al. (2008) and $\mathrm{Ku}-$ mar et al. (2013) in jute sown on first week of june.

In both the experimental years the yield attributes like no of seed pod $^{-1}$, test weight were not influenced significantly with the different agronomic practices, even though, the no. of pod plant ${ }^{-1}$ was significantly influenced. The highest no. of pod plant was recorded with the crop that were topped at 45 DAS; while the least no. of pods plant was recorded with the crop that were grown without any topping practices. However, the topping had a colossal effect on the seed yield and stalk yield of the crop. The best seed yield and stalk yield were documented under the crop topped at 45 DAS; while the least values of seed yield and stalk yield were found with the crop that was grown conventionally i.e. without any topping practices. The reason behind that the clipping off apical buds induces growth of new auxiliary branches and increases the other yield attributes like no. of pod plant ${ }^{-1}$, no. of seed pod $^{-1}$ etc. which consequently results in an increase of seed yield to a sufficient extent. All these results are in concord with the findings recorded by Mollah et al. (2015) in kenaf crop and Das et al. (2014) in white jute (topping at 45 DAS) crop.

Effect of date of sowing and topping on the economics 
of jute seed production: In crop cultivation, farmers are generally interested to produce more per unit of investment of inputs. So, an assessment of quantifying the net profit per unit investment involved in different treatment is necessary to see the overall picture.The cost of cultivation was same for all the three dates of sowing (Table 3). However, it was little more in the second year (Rs. 23589.00) than the first year (Rs. 23038.50). The treatment superiority with consideration to gross return, net return and benefit: cost ratio (1.46 and 1.56 in 2014 and 2015 respectively) were identified with the first date of sowing, while, the minimum values were achieved with the last date of sowing. This may be due to the fact that higher yield obtained due to better interaction of the crop with the environment in early sowing fetched more return, but, the cost of cultivation was same in all the three dates of sowing. Das et al. (2014), Kumar et al. (2013), Singh et al. (2013) also opined in the same way that the sowing on first week of june improved yield as well as economics.

Although the cost of cultivation was same for all the sowing dates, it varied with the different topping practices during both the years. The minimum cost of cultivation (Rs. 21012.00 and Rs. 22078.00 during $1^{\text {st }}$ and $2^{\text {nd }}$ year respectively) was observed under the no topping practices. The cost of cultivation was same and more for the other three toping practices as it includes the labour charges necessary for clipping off the apical portion (Table 3). However, the crop topped at 45 DAS achieved a maximum gross return, net return and benefit: cost ratio (1.52 and 1.61 in 2014 and 2015 respectively) due to the maximum yield realised under it followed by the topping of the crop at 30 DAS. These results are in endorsement with the opinions of Mishra et al. (1998) in tossajute and Das et al. (2014) in white jute where topping was done at 45 days old crop. They stated that though the employment of topping increased the cost of cultivation to some extent over the no topping practices but the significant yield augmentation due to the adoption of topping escalated the production to the sufficient extent, so, gross return, net return and ultimately the benefit: cost ratio became higher over conventional method of cultivation.

\section{Conclusion}

Therefore, from the above experiment, it can be concluded that higher jute seed yield can be obtained from the capsularis variety Bidhan pat-3 under rainfed condition in the red and laterite zone of West Bengal if the seeds are sown during the period of late June to mid-July along with topping at 45 DAS.The topping is advantageous over the conventional method of cultivation and delay in sowing results in poor performance with respect to yield attributing characters and seed yield.

\section{REFERENCES}

Anonymous. (2016). Estimates of area and production of jute in West Bengal-2015-16. Directorate of Jute Development, Ministry of Agriculture, Government of India.

Antia, B.S., Akpan, E.J., Okon, P.A. and Umoren, I.U. (2006). Nutritive and anti-nutritive evaluation of sweet potatoes (Ipomoea batatas) leaves. Pak J. Nutr. 5: 166-168.

Das, H., Poddar, P., Haque, S., Pati, S. and Poddar, R. (2014). Seed yield and economics of white jute as influenced by different dates of sowing, spacing and topping schedule in Terai region of West Bengal. Int. J. Farm. Sci., 4(4): 51-58.

Gomez, K.A. and Gomez, A.A. (1984). Statistical Procedure for Agricultural Res. 2nd Edn. Intl. Rice Res. Inst. Manila, Philippines.

Hossain, M.A, Mannan, S.A., Sultana, K. and Khandakar, A.L. (1994). Survey on the constraints of quality jute seed at farm level. Agril. Support Service Project (GOB/WORLD BANK/ODA). Dhaka, Bangladesh.

Kumar, N., Srivastava, R.K., Singh, R.K. and Singh, M.V. (2013). Impact of Sowing Time and Varieties on Seed Yield of Jute in Subtropical Climatic Zone of North Eastern Uttar Pradesh. Natl. Acad. Sci. Lett.36:571-573.

Mishra, G.C., Kar, A.K., Mahapatra, L.N., Mahapatra, S.S. and Rath, L.K. (1998). Effect of genotypes, sowing date and row spacing with or without clipping on seed yield and occurrence of pests and diseases in jute. Environ. and Ecol. 16(3): 514517.

Mollah, A. F., Rahman, M. M., Tareq, M. Z., Hasan, M. M. andHoque, A. B. M. Z. (2015). Yield and Quality of Kenaf Seed as Influenced by De-Topping and Spacing Under Transplanting Method. Int. J. App. Sci. Biotechnol.3: 626-634.

Rayhan, S.M., Rahman, Md.A. and Amin, M.H.A. (2008). Effect of planting time and magnesium on the growth and yield of jute seed. Bang. Res. Pub. J. 1(4): $303-311$.

Salmasi, S.Z., Golez, K.G. and Moghbeli, S. (2006). Effect of sowing date and limited irrigation on the seed yield and quality of dill (Anethumgraveolens L.). Turk. J. Agric. Forestry, 30: 281-286.

Singh, M.V., Kumar, N. and Kumar, V. (2013). Effect of variety, sowing dates and fertility levels on Capsularis jute. Ann. Pl. Soil Res., 15(2): 179180. 